\title{
Economies Based on Reward Sharing: a Case Study in Indonesia's Tertiary Sector ${ }^{1}$
}

\author{
Umi Karomah Yaumidin \\ Research Center for Economics \\ Indonesian Institute of Sciences
}

\section{Introduction}

Reward-sharing activities are well known in the business world, particularly for businesses relying on trust. Today, the basic concepts of Islamic economics are widely used not only in the banking sector but also in other economic sectors. In Indonesia, the concept of profit and loss sharing (PLS), contract sharing and revenue sharing can be seen as an another model to accelerate growth after cyclic downturns. There are at least three reasons why it is important to examine this concept. First, how it affects lower investment inflows, whether domestic or foreign investment. High corruption, high risk and uncertainty are the most common reasons and influencing factors for investors wanting to invest in Indonesia, although Indonesian governments have been working hard to reduce these handicaps.

Second, there are difficulties for small enterprises in getting funds from formal financial institutions and this contributes to company bankruptcies. As is commonly known, financial institutions require interest fees for credit but many small businesses cannot meet this requirement because they have not enough assets to quarantine their credit.

1 This summary is based on a research report by P2E-LIPI. The research was conducted by Umi Karomah Yaumidin, Jusmaliani, Yani Mulyaningsih, Inne Dwi Astuti and Putri Irma Yuniarti. 
Third, monetary crises cause many financial institutions to have negative growth problems. ${ }^{2}$ However, some studies have found that financial institutions that use reward sharing in their operations were able to avoid financial crises. Some studies of the efficiency of Islamic banks have found that their practices are similar and their efficiencies are on a par with conventional banks. Other studies have found that Islamic banks are efficient in their operations. This affects the business climate; a business that uses reward-sharing practices is more likely to remain operational than a business that depends for its capital on conventional banking, which relies on interest payments as its main source of revenue.

This research paper is concerned with businesses and business practices that endorse the reward-sharing concept. This concept is in line with Islamic economics where capital owners and businessmen are joint venturers in business. It is argued that in this system each party will work to reduce risk, in contrast with those businesses where the risk is taken by one party only, the business. As well, capital placement is not such a burden because the parties are sharing money and the financial management must be more transparent.

In addition, a reward-sharing arrangement curbs, to an extent, the tendency to avarice on the part of capital owners and increases the opportunities of reward for capitalists and for entrepreneurs. Therefore, as Islam teaches us, every transaction should consider justice, fairness, transparency and avoid ushr. Therefore, for these reasons, we hope the result of this study will contribute to the development of Islamic economics.

\section{Method}

\section{Research}

This research is exploratory and involved collecting information from many organisations; government institutions, entrepreneurs and

2 Operational funds are greater than revenue. 
businessmen, financial institutions, capital owners and the general public. However, before this research started, we consulted experts in this topic to share their experiences. We then identified businesses that would be our respondents.

Primary data were collected by observing and interviewing respondents whose businesses are in the hotel, restaurant and telecommunication industries. To support information from business people we also gathered relevant documents; company records, financial statements and the like.

\section{Methods of Analysis}

We analysed the data using qualitative and quantitative methods to discover how internal and external factors affect a company's ability to apply the concept of reward sharing in their businesses.

First, we identified which factors could be categorised as internal or external. Then we analysed the data to get a similar perception from respondents for the same question. We limited the list of questions for specific items to only 10 points to avoid over generalisation.

Second, to complete step 1, we analysed external factors including observations about current national and international situations that affected particular businesses.

Third, internal and external factors are compared by weighting using a 0 to 1 scale. Value 1 for an important point and 0 for unimportant. Then these items are grading using a 1 to 4 scale, where the value 4 is for very strong and 1 is for weak factors. These grades are decided by respondents when they were interviewed. 


\section{Research Variables}

Research variables include

Table 1Determinant Variable

\begin{tabular}{|l|l|l|}
\hline $\begin{array}{l}\text { Categorised } \\
\text { Respondent }\end{array}$ & Tangible Variables & Intangible Variables \\
\hline $\begin{array}{l}\text { Entrepreneur/ } \\
\text { businessman }\end{array}$ & $\begin{array}{l}\text { 1 Capital } \\
\text { 2 Assets } \\
\text { 3 Total Production }\end{array}$ & 1 Skills \\
& 4 Costs of Production & 3 Transparency \\
& 5 Nisbah/reward sharing \\
& ratio & 5 Management \\
& 6 Labour & 6 Access to information \\
& 7 Revenue & \\
& 8 Technology & \\
\hline
\end{tabular}

\section{Results and Discussion}

There are differences that determine the proportions of the reward to be shared. These differences are determined by, first, the initial agreement between the entrepreneur and investors. This agreement could be changed depending on current circumstances, for example, if the agreement gives advantages to one party but a loss for the others.

Second, the scheme and mechanism of the reward sharing. Our research showed that there were many ways of applying these schemes depending on the needs of the entrepreneur and capital. Franchising is common model that we found in tertiary businesses, although this concept can be categorised in many ways too. As well as this concept, we could also see that some businesses used multi level marketing and other techniques based on agreement between the parties to transactions in running their business. In other words, businesses that can use techniques that do not attract interest charges do, in part or in full, subscribe to the concept of reward sharing, and basically this is an Islamic approach but it is also possible to use it in conventional businesses, particularly businesses with networks.

A general SWOT analysis for Indonesia's tertiary sector businesses that use a reward sharing scheme: 
1. According to the Tourism Information Institute, the tourism sector, particularly hotels and restaurants, could account for almost 55 per cent employment in Indonesia (Kompas 2004). On the other hand, tourism is in the third rank as a big contributor to GDP after oil and textiles. In 1996, this sector contributed almost US\$6.3 trillion to GDP, and US\$5.75 trillion in 2000.

2. Stability and security in the tourism industry are important factors in attracting visitors to this region. On the economic side, tourism is beneficial because it will increase Indonesia's reserves. But, social and political conditions in Indonesia are volatile and do not encourage tourism and visitors hesitate to visit Indonesia.

3. There are also some occasional events that can raise incomes, such as public holidays. People tend to look for something different when they want to spend time with their families, college friends or with relatives to celebrate a special occasion. To meet these visitor needs, hotel managements always offer some special package or attraction to be a magnet for visitors. Usually during school holidays the occupancy rate in hotels increases significantly. In contrast, during the fasting month (Ramadan), occupancy rates tend to decrease.

4. The quality of Indonesian human resources is not up to international standards. Human resources should have more knowledge, higher competency and develop the necessary special skills. To raise the quality of human resources, we need comprehensive programs at regional, national and international level. Higher standards of competency assure greater creativity, innovation and productivity in employee performance as individuals or in a team.

5. There is a lack of focus in tourism promotion in Indonesia. Indonesian governments have to develop and promote an image to raise Indonesia's position in selected marketing areas. Indonesia should have a tourism theme to ensure that it is a tourist destination in the travel world. Indonesia's closest competitors are Malaysia with 'Truly Asia', Singapore with 'New Asia' and Thailand with 'Amazing Thailand'. 
6. Indonesia still faces many problems in terms of corruption and illegalities. For example, local government in Bandung put into effect special taxes that discourage visitors, such as a swimming pool tax, a hall tax and so on, and there is a hotel tax that is 10 per cent of hotel revenue. On the other hand, there have been travel bans and travel warnings since the tsunami disaster in Aceh, the earthquake in Yogyakarta and the terrorism attack in Bali; these also contribute to reducing the number of foreign visitors. Indonesia has become or has been seen to be a country with a high risk for visitors and this reduces potential income from the tourism sector.

7. These conditions discourage investment. Another reason is that the gross operating profit (GOP) in the hotel business is low, about 45 per cent (Kompas 2004). If GOP were to reach 45 per cent and tourism growth by about 15 to 20 per cent, investors would be interested in building hotels because the pay off period can be reached after eight or nine years. After the crises in 1997, the payback period on average for any business is about 16 to 18 years.

8. In terms of rewards, businesses in tertiary sectors do not have the benefits of a legal framework of support; the mechanisms and models only refer to interest-free banking. But reward-sharing schemes are possible in all businesses in service industries.

\section{Reward Sharing Based in Hotels}

Our analysis found that there are three hotels that can be categorised as successful businesses that have applied reward sharing scheme: the Sofyan Betawi Hotel, Cottage Darut Tauhid and Gadjah Mada guest house.

Internal factors have a score of 3.10, which show that its position is stronger than an external one. External factors only have a score of 2.7. What this means is that there are key internal factors that contribute to a business's success, such as its capability of absorbing workers, the tourism benefits that the hotel can offer and social and political factors that have a direct effect on the hotel. Key external factors that influence the success of this type of business is the opportunity it has to attract 
visitors, and travel bans by governments of foreign countries that are the source of tourists.

The hotel business is in the IV quadrant with a total score IFE of 3.1 (strong) and total score EFE of 2.7 (medium). Therefore, this type of business can be categorised as a grow and build business. This business category should undertake intensive strategic planning in terms of market segmentation, market penetration and developing products to make the business competition proof.

To decide which strategies can best develop business in the hotel industry, we can use a TOWS matrix. This matrix considers a combination of steps in strength, opportunity, weakness, and threats (SWOT) factors. First, strategy SO for example, we can use our strength to create opportunities in front of us. Second, strategy WO can be used to overcome weaknesses by benefitting from opportunities. Third, we can use our strength to avoid threats and challenges by applying ST strategies. Last, strategy WT can be used to reduce weaknesses and avoid threats and challenges.

\begin{tabular}{|c|c|}
\hline \begin{tabular}{|ll} 
Strategy SO \\
$1 \quad \begin{array}{l}\text { Hotel management should } \\
\text { arrange cooperation with travel }\end{array}$ \\
& agents and airline companies to \\
& integrate tourism packages. \\
2 & Arranging cooperation with either \\
& shari'a or conventional banking \\
& to promote tourism with special \\
& discounts or special rates.
\end{tabular} & \begin{tabular}{|l}
$\begin{array}{l}\text { Strategy WO } \\
1\end{array}$ \\
$\begin{array}{l}\text { Encourage good relations between } \\
\text { capitalists and entrepreneurs to } \\
\text { create trust and transparency. } \\
2\end{array}$ \\
$\begin{array}{l}\text { Making legal contracts or } \\
\text { agreement about reward sharing } \\
\text { with trustworthy institutions to }\end{array}$ \\
anticipate unpredicted events. \\
3 Encourage social and political \\
stability in the local area. \\
4
\end{tabular} \\
\hline
\end{tabular}




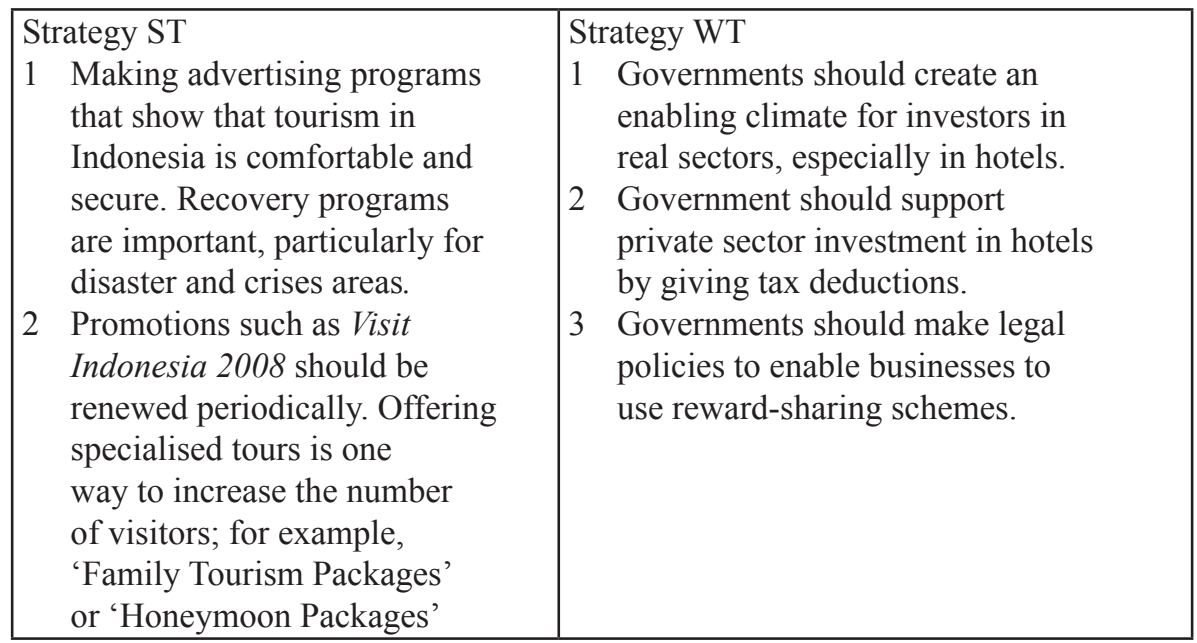

\section{Reward Sharing Based in Restaurants}

There are many models of reward sharing to be found in restaurant businesses. Padang (West Sumatra) restaurants still use pure reward sharing, the owner cooperates with an investor and their workers. In this context, there are two models; first, there is the model involving two parties only: investor and owner who share the risks and rewards (50:50) in nisbah. Second, there are three parties in cooperation and the sharing becomes 50 per cent for workers and 50 per cent for the investor. The investor's share subdivides into 35 per cent for the investor and 15 per cent for the owner or manager. Percentages for each employee will be according to duties and experience in such work.

In the case of Bubur Mang Oyo, which is in West Java, the owner of the building and the food supplier cooperate each other in a 20:80 division of total revenue. At the start of the contract, the building owner received about 18 per cent, thus the food supplier received about 82 per cent. During the period of the contract, nisbah or proportion of reward sharing, could be changed according to the needs of the two parties to the agreement. Different from that case, in Yogyakarta, we found that contracts between capitalists and entrepreneurs who manage a resort with a restaurant that the proportions are 30 per cent for entrepreneurs and 70 per cent for investors. We also found that when the business 
involves three parties that the shares are of the order $35: 35: 30$. This proportion has been determined by the amount of money each party has invested and the kind of services provided by those who operate the business.

External factors are very influential in the efficient operation of a restaurant and a reward-sharing system helps ensure that these are kept under control. The IF and EF matrix give an internal score (2.13) that is lower than that for external factors (2.55). This makes sense because these businesses are dependent on consumer tastes and preferences that can change quickly.

Business restaurant scores in the IV quadrant with total scores of IFE 2.13 (medium) and a total score of EFE 2.55 (medium). Therefore, this type of business can be categorised as hold and maintain businesses. Such businesses should use intensive strategies to do with market segmentation, market penetration and they should develop products that will ensure the business's continuity and that it can withstand competition.

To decide which strategies are the most effective we can use a TOWS matrix.

\begin{tabular}{|c|c|}
\hline Strategy SO & Strategy WO \\
\hline $\begin{array}{l}\text { 1. The management of restaurant } \\
\text { should cooperate with shari'a and } \\
\text { conventional banking to promote } \\
\text { shopping tourism packages with } \\
\text { special discounts. } \\
\text { 2. Entrepreneurs should use their } \\
\text { creativity to invent new menus that } \\
\text { can attract more customers. } \\
\text { 3. It is better to expand businesses by } \\
\text { establishing branches in Indonesia. }\end{array}$ & $\begin{array}{l}\text { 1. Encourage good relations between } \\
\text { capitalist and entrepreneur to create } \\
\text { trust and transparency. } \\
\text { 2. Making legal contracts about reward- } \\
\text { with trusted institution to anticipate } \\
\text { unpredictable events. } \\
\text { 3. The restaurant management should } \\
\text { standardise their menus and recipes } \\
\text { to increase customer satisfaction. } \\
\text { 4. Modern management is an another } \\
\text { way to make Indonesian restaurants } \\
\text { better. }\end{array}$ \\
\hline
\end{tabular}




\begin{tabular}{|l|l|}
\hline Strategy ST & Strategy WT \\
$\begin{array}{l}\text { 1. To protect their recipes, restaurants } \\
\text { should register them to ensure } \\
\text { intellectual rights for any menu that } \\
\text { they have created. }\end{array}$ & $\begin{array}{l}\text { Government should create conducive } \\
\text { climate for investment in the real } \\
\text { sector, especially in restaurants. } \\
\text { food and services to ensure consumer } \\
\text { trust and satisfaction }\end{array}$ \\
$\begin{array}{l}\text { Government should make legal } \\
\text { policies to enable restaurants to use } \\
\text { reward-sharing schemes. }\end{array}$
\end{tabular}

\section{Reward Sharing in Telecommunications}

There are two models of the reward sharing concept in telecommunications. First, internet stalls tend to use a franchising model. This model is one of cooperation between entrepreneur and investors. Usually, the entrepreneur sells their brand to people who want to invest in this business. It has been noted that franchising businesses should have a unique product and offer special services. Therefore, such businesses can compete with similar businesses. Second, cooperation between telephone stall owners and PT. Telkom as the provider. According to the contracts that have been approved by PT. Telkom, entrepreneurs receive 30 per cent of total income from PSTN services, and 20 per cent from pulsa for STBS access over airtime. In addition, the PT. Telkom partner will receive reward sharing from multimedia products, that is, TelkomGlobal-017 is about 10 per cent; internet access services is about 30 per cent for accessing for the first 10 hours; 15 per cent from total revenue of international call services (TIC-007); and last, 0 per cent for short message services (SMS).

Internal factors have a score of 2.47, which shows that its position is stronger than external. External factors only have a score of 2.28. This means that it is key internal factors that have a greater influence on a company's success and its ability to adapt to current technology.

Businesses in telecommunications are on the $\mathrm{V}$ quadrant with a total score IFE of 2.47 (medium) and total score EFE 2.28 (medium). Therefore, these businesses can be categorised as hold and maintain businesses. Such businesses should include in their planning strategies some market 
segmentation, market penetration and product development product to ensure the business's continuation and to resist competition.

In considering the strength, opportunity, weakness and threats factors we use a TOWS matrix.

\begin{tabular}{|c|c|}
\hline $\begin{array}{l}\text { Strategy SO } \\
\text { 1. To develop this type of business, } \\
\text { entrepreneurs should collect } \\
\text { information about consumer needs in } \\
\text { the target market. } \\
\text { 2. Entrepreneurs could cooperate with } \\
\text { shari'a banking for funds to expand } \\
\text { their business. }\end{array}$ & $\begin{array}{l}\text { Strategy WO } \\
\text { 1. Entrepreneurs should take fast } \\
\text { action to keep up with changes in } \\
\text { technology. } \\
\text { 2. To increase profits, businessmen } \\
\text { could choose providers who offer } \\
\text { cheaper rates for connection. } \\
\text { 3. Reward sharing could be an another } \\
\text { solution to maintain their business. } \\
\text { This concept can be applied when } \\
\text { looking for either a new investment } \\
\text { partner or new employees. }\end{array}$ \\
\hline Strategy ST & Strategy WT \\
\hline $\begin{array}{l}\text { 1. Government should create an } \\
\text { investment climate that would } \\
\text { encourage investment in real sectors, } \\
\text { especially telecommunication. } \\
\text { 2. Government should make legal } \\
\text { policies to regulate businesses that use } \\
\text { reward sharing. } \\
\text { 3. Governments should support } \\
\text { private sector investment in } \\
\text { telecommunications by allowing tax } \\
\text { deductions. } \\
\text { Entrepreneur should adapt to any } \\
\text { changes in global technology to } \\
\text { insulate their business from loss. }\end{array}$ & $\begin{array}{l}\text { 1. Entrepreneurs should the } \\
\text { development of technology. } \\
\text { 2. Following rules and regulations } \\
\text { pertaining to business will create a } \\
\text { better environment for businesses } \\
\text { in general. }\end{array}$ \\
\hline
\end{tabular}

\section{Policy Recommendations}

Overall, SWOT analysis before weighting described the external factors (opportunities and threats) that are the dominant factors influencing business in tertiary sectors. Internal factors only contribute 25 per cent to business conditions. This implies that tertiary sectors are susceptible to volatility and to social and political dynamics. Most companies could not handle force majeure factors such as a natural disaster, earthquake 
and so on. However, they should adapt to any changes in government regulation and to new competitors.

Businessman should manage opportunities to expand their business and take more advantages from that. The large number of people in Indonesia comprise a potential market for businesses in hotels, restaurants and telecommunications. Moreover, the current Indonesian economy is in better shape now than it was after the crises of 1997.

Generally, the strengths and weaknesses of companies did not cause problems for them. Problems stemmed from specific characteristic of such businesses and the ability of entrepreneurs to anticipate and hold out their business from challenge and threats. Therefore, choosing the right strategic plan for each company becomes a key to the success of business.

By giving equal weighting for each item of internal and external factors, it can be concluded that business in restaurant and telecommunication can be categorised as 'hold and maintain', and businesses in hotels is 'grow and build'. The grand strategy that should be taken by each business is intensive strategy. The reason is that because businesses that incorporate reward sharing are relatively new in Indonesia; the cycles of such businesses is a subject for study and research. Thus, many people are interested to find ways of achieving high returns in this category of business.

\section{References}

\section{Books and Journals}

David, FR. 1998. Concept of Strategic Management, 7th edn. Upper Saddle River, New Jersey: Prentice Hall Inc.

------. 2003. Strategic Management: Concepts and Cases, 10th edn. New Jersey: Prentice Hall International.

Jusmaliani (ed.). 2006. Aktivitas Ekonomi Berbasis Bagi Hasil di Sektor Sekunder. Jakarta: Pusat Penelitian Ekonomi (P2E)-LIPI.

Muhammad. 2002. Manajemen Bank Syariah. Yogyakarta: UPP AMP YKPN.

Statistik Perhubungan. 1999. Badan Pusat Statistik, Indonesia. 
Statistik Perhubungan. 2004. Badan Pusat Statistik, Indonesia.

Thoha, Mahmud (ed.). 2005. Aktivitas Ekonomi Berbasis Bagi Hasil. Jakarta: Pusat Penelitian Ekonomi (P2E)-LIPI.

Undang-Undang Republik Indonesia.1999. No. 36. 8 September 1999.

\section{Websites}

Awari 2007. 'Sejarah Awari'. http://www.awari.or.id/, accessed 26 October 2007.

Bisnis Waralaba Indonesia. 2006. http://www.franchise-indonesia.com/, accessed 20 November 2007.

Damanhuri, LA. 2008. 'Kondisi dan Status Sektor Telekomunikasi'. http://kkppi. go.id/dloads/kondstel.pdf, accessed 12 November 2007.

Departemen Kebudayaan dan Pariwisata. 2006. 'Konsep dan Definisi'. http://www. budpar.go.id/, accessed 12 September 2007.

Gozali, A. 2003. 'Sistem Bagi Hasil'. http://finance.groups.yahoo.com/, accessed 15 October 2007.

Kompas. 2002. 'Kompetisi boleh, tetapi bagaimana bentuknya'. http://www2.kompas. com/, accessed 11 November 2007.

Kompas. 2004. 'Hingga tahun 2006, penyerapan tenaga kerja sektor pariwisata rendah'. http://kompas.com/, accessed 20 June 2007.

Kadin. 2006. 'Untuk pengembangan kepariwisataan, masih memerlukan pengkajian'. , accessed 6 November 2007.

Netindo. 2007. 'About Netindo (tentang Netindo): tak kenal maka tak sayang sekilas tentang kami karena kami ingin mengenal anda lebih jauh lagi'. http://www. netindo.net/, accessed 26 October 2007.

-----. 2007. 'Investment (investasi): kepercayaan anda adalah yang utama, pengalaman adalah guru yang setia, integritas adalah segalanya'. http://www.netindo.net/, accessed 26 October 2007.

Purnama, YH. 2006. 'Epidemi Tren Konsep Bisnis Waralaba'. http://www.franchiseindonesia.com/, accessed 5 November 2007.

Republika. 2000. 'Bisnis Perhotelan : Jelas tapi kurang dilirik'. http://republika.co.id/, accessed 15 July 2007.

Republika. 2003. 'Riyanto Sofyan kukuh terapkan aturan syariah di hotel'. http:// www.republika.co.id/, accessed 18 October 2007.

Republika. 2004. 'Bisnis syariah makin berkibar'. http://www.republika.co.id/, accessed 23 August 2007.

Satriya, E. 2002. 'Otokritik : mengapa telematika Indonesia masih terpuruk?' http:// www.ia-itb.com/, accessed 12 November 2007.

Siwah. 2007. 'CSR ala hotel Sofyan'. http://siwah.wordpress.com/, accessed 10 November 2007. 
